\title{
The Role of Linguistic Typology, Target Language Proficiency and Prototypes in Learning Aspectual Contrasts in Italian as Additional Language
}

\section{Francesco Vallerossa (D)}

Citation: Vallerossa, Francesco. 2021.

The Role of Linguistic Typology,

Target Language Proficiency and

Prototypes in Learning Aspectual Contrasts in Italian as Additional

Language. Languages 6: 184.

https://doi.org/10.3390/

languages6040184

Academic Editor: Lisa A. Reed

Received: 7 September 2021

Accepted: 29 October 2021

Published: 5 November 2021

Publisher's Note: MDPI stays neutral with regard to jurisdictional claims in published maps and institutional affiliations.

Copyright: (C) 2021 by the author. Licensee MDPI, Basel, Switzerland. This article is an open access article distributed under the terms and conditions of the Creative Commons Attribution (CC BY) license (https:/ / creativecommons.org/licenses/by/ $4.0 /)$.
Department of Language Education, Stockholm University, Universitetsvägen 10E, SE-106 91 Stockholm, Sweden; francesco.vallerossa@isd.su.se

\begin{abstract}
The study examines how prototypes and typological relationships between the L1, the L2 and the target language (TL) interact with TL proficiency in learning Italian as additional language. Low-proficiency and high-proficiency undergraduate learners of Italian $(\mathrm{N}=25)$ with Swedish as L1 performed an oral retelling story test, aiming to elicit the Italian aspectual contrast perfectiveimperfective. Their tense selection was analyzed considering the predicates' lexical aspect and the learners' knowledge of a Romance L2, or lack thereof. The findings show that the typological proximity between the L2 and the TL exerts a differential role depending on TL proficiency. Initially, it is beneficial for accelerating the overall emergence of the imperfetto as an aspectual marker. However, the prototype factor and, more specifically, the predicates' dynamicity influences the selection of past inflectional morphology. At more advanced stages, knowledge of a Romance language helps learners move beyond prototypical associations with the passato prossimo, but it does not seem to influence the use of the imperfetto among high-proficiency learners. These results are discussed in the light of research on the second and additional language learning of aspectual contrasts in Romance languages.
\end{abstract}

Keywords: tense-aspect; Italian; additional language learning; proficiency

\section{Introduction}

Previous research on the second language acquisition of the Romance contrast between perfective and imperfective aspect has found several important factors that play a role when learning how to express tempo-aspectual (TA) morphology (Bardovi-Harlig and ComajoanColomé 2020). One of those factors is the influence of prototypical associations of lexical and viewpoint aspect (henceforth, the prototype factor). In fact, learners seem to consistently produce these associations at some point in the development of TA morphology (Andersen 1993; Shirai and Andersen 1995). A second important factor is the typology factor, namely whether there is transfer in the realm of aspect due to typological relationships of proximity and distance between previously known languages (both the L1 and L2) and the target language (TL) (for the influence of the L1 in L2 acquisition see Collins 2002; Izquierdo and Collins 2008; for the influence of the L2s in additional language learning see Diaubalick et al. 2020; Eibensteiner 2019; Foote 2009; Salaberry 2005; Vallerossa et al. Forthcoming). These two factors interact with a third factor, which is TL proficiency, but their impact varies at different acquisition stages (McManus 2011, 2015; Salaberry 2008).

Cross-linguistic inconsistencies or similarities between the L1 and the TL in marking aspect may complicate or accelerate the learning process, especially during initial stages of acquisition. However, L1-related differences tend to be less prevalent as TL proficiency increases (McManus 2011, 2015). Furthermore, a few studies on the additional language learning (henceforth, Ln learning) of aspect, focusing on interpretation data and selection tasks, found transfer of knowledge in the aspectual domain from the L2s to the TL. Specifically, L2 proficiency, understood as knowledge of aspectual contrasts in the L2s, 
was a prerequisite for transfer to occur (Eibensteiner 2019; Vallerossa et al. Forthcoming). In addition, the typological similarity between the L2 and the TL contributed to transfer (Diaubalick et al. 2020; Foote 2009; Salaberry 2005, 2020). Although the influence of TL proficiency was not investigated in these studies on the acquisition of aspect, research on multilingual transfer found that L2 influences are strongest during the initial stages of acquisition of an Ln while they decline with increased TL proficiency (Bardel and Lindqvist 2007; Sánchez and Bardel 2017; Williams and Hammarberg 2009).

Hence, transfer from the L1 and the L2s seems to influence the interlanguage of beginner learners while the tense selection of advanced learners appears, with time, to become relatively homogeneous regardless of previously known languages. Seemingly, the learners' interlanguage is driven at advanced stages by the prototype factor, as they tend to consistently adhere to certain associations of lexical and viewpoint aspect, defined as prototypical.

Based on previous research, there are three major research gaps to fill. First, there is a need to address whether learners' knowledge of a L2 that is typologically similar to the TL, such as two Romance languages, comes into play in tasks requiring the production, and not only the interpretation, of TA morphology. For that reason, the present research focuses on oral production data. Second, if there is influence from a typologically similar L2, it is important to investigate how it changes with increased TL proficiency. Third, it is crucial to examine whether the same semantic principles, found in previous studies looking at learners approaching a chronologically true second language, are also relevant for multilingual speakers.

Given this background, the present study aims to contribute to research on learning an Ln, with a focus on Romance languages, by looking at how multilingual learners express TA morphology in Italian as Ln. To this aim, undergraduate L1 Swedish speakers learning Italian $(\mathrm{N}=25)$ at different proficiency levels (i.e., low, high) performed an oral retelling story test in Italian, focusing on two aspectual meanings, perfective and imperfective habitual. The participants were divided into a non-Romance group $(n=10)$ and a Romance group $(n=15)$, depending on whether they had additional knowledge of a Romance language or not.

In the analysis of the data, the dependent variable was the learners' selection of TA morphology in Italian (e.g., passato prossimo or imperfetto). The three independent variables were the typological relationships between the L1, the L2 and the TL (i.e., the typology factor), the learners' proficiency in the TL (i.e., the proficiency factor) and the type of predicate chosen by them (i.e., the prototype factor). The latter was operationalized in terms of type of verb predicates produced by the learners (i.e., telic, activities, states) in relation to a tense form. The typology factor accounted for, at the same time, the linguistic distance between the L1 (i.e., Swedish) and Italian, and the linguistic similarity between the L2 (i.e., a Romance language) and Italian. While all the learners had Swedish as L1, there was a group with additional knowledge of a Romance language as L2. Hence, it was possible to investigate the effects of linguistic proximity through the L2-related distinction between a Romance group and a non-Romance group. Finally, proficiency in Italian, measured by a C-test, was reflected in the distinction between low-proficiency and high-proficiency learners.

\section{Learning Aspectual Morphology in Romance Languages}

The acquisition of the contrast existing in Romance languages between perfective and imperfective aspect is by far one of the most troublesome areas for foreign language learners to master (Blyth 2005). As already mentioned, two important factors, among others (Bardovi-Harlig and Comajoan-Colomé 2020), have been advocated in previous studies as responsible for the learning trajectory of TA morphology: the typology factor, entailing transfer in the realm of aspect due to typological relationships between previously known languages and the target language (TL), and the prototype factor, meaning the semantic congruence between lexical and viewpoint aspect. 
The latter factor is generally connected to the so called 'Lexical Aspect Hypothesis' (henceforth, LAH; Andersen 1993; Shirai and Andersen 1995), and especially to its successive refinements over the years. The LAH makes two major assumptions with respect to the acquisition of perfective and imperfective morphology in Romance languages. First, there is a primacy of aspect over tense in the acquisitional pattern of TA morphology. Second, according to the LAH, when learners of a Romance language start to inflect verbs in the past, they follow a similar pattern, constrained by the predicates' semantic meanings, also known as lexical aspect. Learners start by producing perfective morphology with so called telic predicates, which have an intrinsic culmination, e.g., 'to open' (Comrie 1976, p. 45). Perfective morphology is then extended to atelic predicates that lack an intrinsic culmination, first to activities, i.e., atelic and dynamic verbs such as 'to drink', and finally to states, denoting a condition or a state, e.g., 'to be'. Imperfective morphology is acquired at a later stage and follows the opposite pattern, appearing primarily with atelic predicates and at a final stage with telic predicates.

The influence exerted by prototypical associations, such as telic/perfective and atelic/imperfective, is due to the semantic congruence between lexical aspect and viewpoint aspect (the Congruence Principle; Shirai and Andersen 1995). Moreover, prototypical associations are more frequent in the input that learners are exposed to, hence making them more salient than non-prototypical associations, such as atelic/perfective and telic/imperfective (The Distributional Bias Hypothesis; Andersen 1993; Wulff et al. 2009). According to the LAH, learners will eventually incorporate the entire array of combinations as TL proficiency increases, thus being able to produce perfective and imperfective morphology regardless of lexical aspect.

Over the years however, a few remarks have undermined the validity of the LAH. It is not clear when, in the developmental pattern, the effect of lexical aspect is at its peak on the selection of TA morphology; the LAH predicts that prototypical associations are typical of initial stages whereas other studies found them in the interlanguage of advanced learners (Salaberry 2000, 2008). Another concern is what type of associations to consider as prototypical. Several studies do not agree on the fact that telicity is the crucial semantic property responsible for prototypicality; instead, it is contended that dynamic predicates, including telic predicates and activities, are those triggering perfective morphology while states attract imperfective morphology (Bergström 1995; Domínguez et al. 2013; González and Hernández 2018). Finally, studies conducted in formal instructional settings (Salaberry 2000), but also studies on bilingual children of school age (Wiberg 1996), showed that the learners' first distinction is temporal and not aspectual. Initially, learners tend to use a default past tense form marking past temporality, regardless of the predicates' lexical aspect, which challenges the LAH in its entirety (the "Default Past Tense Hypothesis", henceforth, DPTH; Salaberry 2008; Wiberg 1996). Crucially, the DPTH accounts for L1 transfer, at least for L1 English speakers learning a Romance language as L2. Accordingly, they will initially equate the English Simple Past with the Spanish preterito indefinido (Salaberry 2008).

Parallel to the successive developments of the LAH, not least from the formulation of the DPTH, the role exerted by the L1 has also been thoroughly investigated in aspectual studies. There has been a trend in aspectual studies to examine learners of the same TL but with different L1s to bring out L1-specific effects (Collins 2002; González and Hernández 2018; Izquierdo and Collins 2008; McManus 2011, 2015). In these studies, two insights were gained: first, an L1 that is typologically similar to the TL facilitates the transfer of forms being equivalent in both languages (e.g., Collins 2002; Izquierdo and Kihlstedt 2019), as for instance the present perfect in English and the compound past tense form passé composé in French. Second, in spite of a mismatch of surface forms, the grammaticalization of an aspectual meaning accelerates the remapping of the same underlying meaning onto a different target form. To give an example, research has shown that it is easier for an English L1 speaker of L2 French to acquire the progressive meaning of imparfait than for a Swedish L1 speaker, since English, but not Swedish, has a morphological device that marks progressivity (Howard 2005; Kihlstedt 2002; Labeau 2005). More importantly, in 
studies investigating the interaction of the typology factor and the prototype factor with the proficiency factor (McManus 2011, 2015), it seems that L1-related differences are stronger at initial stages while they tend to disappear at more advanced stages. In fact, advanced learners seem to be uniformly influenced by prototypes regardless of their L1, which also is in line with the successive refinements of the LAH presented previously.

Simultaneous to this interest about the role of cross-linguistic similarities between the L1 and the TL, the impact of foreign languages learnt later in life on the acquisition of a new non-native language has been gaining ground over the past three decades. With the exception of Salaberry (2005), it was not until the last decade that this issue started to be thoroughly addressed in aspectual studies. A few of these studies considering the influence of previously learnt languages have identified two relevant factors: the typology factor operating between the L2 and the TL, and the proficiency factor in the L2, not to be confounded with the proficiency factor in the TL presented previously. As for typology, knowing a L2 that is related and, hence, similar in many respects to the TL, facilitates transfer of knowledge in the realm of aspect. This held true both for languages of the same family, for example two Romance languages, and for languages that, in spite of their belonging to different families, codify aspect similarly. The former is the case of English L1 speakers having knowledge of a Romance language as L2 approaching another foreign Romance language (Diaubalick et al. 2020; Foote 2009; Salaberry 2005). The latter regards speakers of a Germanic language as L1 learning a Romance language as L3 with knowledge of English as L2 (Eibensteiner 2019; Vallerossa et al. Forthcoming). In both cases, the fact that the L2, if compared to the L1, was typologically closer to the L3 enhanced positive transfer. As for proficiency, being proficient in the L2 was a prerequisite in order for transfer to take place. In Eibensteiner (2019) and Vallerossa et al. (Forthcoming), learners, divided into a low-proficiency and a high-proficiency group according to their aspectual knowledge in English, completed interpretation tests in Spanish and Italian, respectively. Both studies found that learners with high proficiency in English were more accurate in their aspectual choices than learners with low proficiency in English.

A final concern regards the prototype factor in Ln learning. Salaberry $(2005,2020)$, Diaubalick et al. (2020), and Vallerossa et al. (Forthcoming) found differential learning paths for prototypical and non-prototypical associations; these studies indicate that knowledge of a Romance language facilitates the acquisition of prototypical associations while the L1 still constrains the acquisition of non-prototypical meanings (Salaberry 2020). In these studies, associations of states and perfective morphology were those affected by L1 constraints, thus causing difficulties for learners.

In summary, there is evidence from studies on the L2 acquisition of TA morphology that the typology factor and the prototype factor interact with TL proficiency. At initial stages, the L1 influence seems to be more prevalent while L1-related differences tend to flatten out with increased TL proficiency. Research on the Ln learning of aspect found that the typology factor has to be understood not only with reference to the L1 but also to other formerly learnt languages.

However, when it comes to the Ln learning of aspectual contrasts, there is no agreement on the role played by prototypes, i.e., whether they are equally strong among multilingual learners as they are among true second language learners. In addition, it is not clear how the prototype factor and the typology factor (L1, L2, TL) interact with TL proficiency.

Finally, although there is a large amount of L2 acquisition studies focusing on production data, Ln aspectual studies have looked at interpretation data or selection tasks; research has yet to address how aspectual knowledge is expressed in production data when approaching an Ln that encodes aspect similarly to a previous L2. Oral production and comprehension engage two different cognitive processes, each involving different constrains, for example the time available for producing the language output. Referring to Ln learning, Hammarberg $(2009$, p. 8) argues that it is important to keep production and comprehension separate "partly since decoding linguistic input occurring in a given context works under different conditions than encoding a self-generated message in linguistic 
form, and partly because the two types of processes alternate and interact in the course of language acquisition". Hence, the effects of TL proficiency and linguistic proximity between the L1, the L2s and the TL might be different for interpretation and production tasks.

\section{Tense and Aspect in Swedish and Romance}

Tense is a deictic category and refers to the external temporal structure expressed by a verb whereas aspect, also known as viewpoint aspect (Smith 1997), indicates "the different ways of viewing the internal temporal constituency of a situation" (Comrie 1976, p. 3). Aspect is an inflectional category but, unlike tense, it projects "a particular 'viewpoint' on the situation described by the sentence" (Klein 2009, p. 52).

Viewpoint aspect is codified differently across languages: some languages convey it morphologically whilst other do so lexically. This cross-linguistic inconsistency is believed to generate difficulties for learners. The focus of the present study is on two aspectual meanings in the past: perfective and imperfective habitual. However, it is important to bear in mind that there exist other aspectual meanings which are not investigated here, e.g., imperfective progressive. Perfective refers to a concluded situation, habitual to a habit in the past and progressive to an ongoing situation. These aspectual meanings are expressed differently in Swedish and Romance languages. As shown in Table 1, Swedish has one ambiguous tense, the preteritum, expressing the three meanings. Additionally, there is a lexical device expressing habitual aspect, namely the verb bruka ("to use to") in the past, and different periphrases, such as the one with hålla på att + infinitive ("to keep" +Ving), expressing progressive aspect (Blensenius 2013).

Table 1. Codification of perfective, imperfective habitual and imperfective progressive aspect in Swedish and Romance languages (Italian, French, Spanish).

\begin{tabular}{|c|c|c|}
\hline & Swedish & Romance \\
\hline Perfective & $\begin{array}{l}\text { Jag läste en bok igår } \\
\text { 'I read.PAST a book yesterday' }\end{array}$ & $\begin{array}{c}\text { Ho letto un libro ieri } \\
\text { J'ai lu un livre hier } \\
\text { Lei un libro ayer } \\
\text { 'I read.PERF a book yesterday' }\end{array}$ \\
\hline $\begin{array}{l}\text { Imperfective } \\
\text { Habitual }\end{array}$ & $\begin{array}{l}\text { Jag läste mycket som barn } \\
\text { 'I read.PAST a lot as a child' }\end{array}$ & $\begin{array}{c}\text { Da piccolo leggevo molto } \\
\text { En tant qu'enfant je lisais beaucoup } \\
\text { De pequeño leia mucho } \\
\text { 'As a child I read.IMP a lot' }\end{array}$ \\
\hline Imperfective Progressive & $\begin{array}{c}\text { Jag läste en bok igår } \\
\text { 'I read.PAST a book yesterday' } \\
\text { Jag höll på att läsa en bok igår } \\
\text { 'I keep on.PAST to read.INF a } \\
\text { book yesterday' }\end{array}$ & $\begin{array}{c}\text { Leggevo un libro ieri } \\
\text { Je lisait un livre hier } \\
\text { Leía un libro ayer } \\
\text { 'I read.IMP a book yesterday' }\end{array}$ \\
\hline
\end{tabular}

Romance languages have two past tenses that also convey aspectual information: a perfective tense (passato prossimo in Italian, passé composé in French, preterito indefinido in Spanish) expressing perfective aspect, and an imperfective tense (imperfetto in Italian, imparfait in French, imperfecto in Spanish) conveying habitual and progressive aspect. Progressive aspect can also be expressed through periphrases, especially in Spanish (estar + gerund) and Italian (stare + gerund) (Bardovi-Harlig and Comajoan-Colomé 2020). Arguably, the inconsistency of the Swedish preteritum, together with the existence of competing lexical devices, complicates the linear remapping process of these meanings onto Romance languages. 


\section{The Study}

As mentioned above, the present study aims to provide more insights into the field of research in Ln learning, by looking at how prototypes and typological relationships between the L1, the L2 and the TL interact with TL proficiency when learning TA morphology in Italian as additional language. For this purpose, the following research question is addressed:

What are the effects of typology and prototypicality at different proficiency levels in Swedish L1 speakers' expression of TA morphology in Italian as additional language?

In order to answer the research question, the study looks at how undergraduate learners at different proficiency levels $(\mathrm{N}=25)$, i.e., low and high, learn to express TA morphology in Italian as Ln. They were divided into a Romance and a non-Romance group according to whether they had knowledge of a L2 Romance language or not. All learners had additional knowledge of English as L2, as a level corresponding to the B2.2 in the Common European Framework for Languages (Council of Europe 2001) is an entry requirement for undergraduate studies of Italian in Sweden. Moreover, participants had knowledge of other L2s besides English and Romance languages, e.g., German, but knowledge of these languages was not controlled for in the present study. This type of multilingual background is common in Sweden, since Italian is rarely approached as the chronological true second language (Bardel 2006). The participants performed an oral retelling story test in Italian, which focused on two aspectual meanings, perfective and imperfective habitual. The test was designed to prompt prototypical and non-prototypical associations of lexical and viewpoint aspect.

\section{Materials and Methods}

\subsection{Material}

The material for the data collection of the present study is an oral retelling story test, the "Sisters' Story", a picture story adapted from the SPLLOC project. ${ }^{1}$ This test has been used in several studies (Domínguez et al. 2013; McManus 2011, 2015) investigating the acquisition of TA morphology in Spanish and French. The test was adapted to Italian and aimed to elicit past tense forms including prototypical and non-prototypical associations.

The picture story is about two sisters travelling to Spain. In the test, there are two aspectual shifts, one from perfective to imperfective habitual, and another from imperfective habitual to perfective. Verb predicates in infinitive form were indicated in brackets under each picture. In perfective contexts, past time adverbials or expressions, oftentimes providing an exact time indication, were supplied in order to elicit the passato prossimo, such as nel mese di luglio 2006 ("in the month of July, 2006") (see Appendix A). In imperfective habitual contexts, adverbials or expressions indicating habituality were provided in order to elicit the imperfetto, such as tutti i fine settimana ("every weekend") (see Appendix B).

Table 2 shows the combinations of lexical aspect and viewpoint aspect tested in the oral retelling story test. In total, 23 items tested six conditions combining three classes of lexical aspect (states, activities, telic) and two viewpoint aspects (perfective, imperfective habitual). This resulted in 11 prototypical associations and 12 non-prototypical associations. The former consisted of five perfective/telic and six imperfective habitual/atelic, of which one state and four activities, while the latter consisted of six imperfective habitual/telic and six perfective/atelic, of which two states and four activities. 
Table 2. Combinations of lexical aspect (states, activities, telic) and viewpoint aspect (perfective, imperfective habitual) in the oral retelling test.

\begin{tabular}{|c|c|c|c|}
\hline & States & Activities & Telic \\
\hline Perfective & $\begin{array}{l}\text { (riflettere) sulla causa } \\
\text { dell'incidente } \\
\text { "reflect on the cause of the } \\
\text { accident" } \\
\text { (avere) posti nuovi } \\
\text { "have new seats" }\end{array}$ & $\begin{array}{c}\text { (mangiare) tapas } \\
\text { "eat tapas" } \\
\text { (bere) vino } \\
\text { "drink wine" } \\
\text { (visitare) la città } \\
\text { "visit the city" } \\
\text { (parlare) della loro infanzia } \\
\text { "talk about their childhood" }\end{array}$ & $\begin{array}{c}\text { (prendere) il treno } \\
\text { "take the train" } \\
\text { (sentire) gocce d'acqua } \\
\text { "feel water drops" } \\
\text { (tranquillizzarsi) } \\
\text { "calm down" } \\
\text { (chiedere) aiuto al controllore } \\
\text { "ask the ticket collector for help" } \\
\text { (essere) un incidente1 } \\
\text { "have an accident" }\end{array}$ \\
\hline Imperfective Habitual & $\begin{array}{l}\text { (essere) molto diverse } \\
\text { "be very different" }\end{array}$ & $\begin{array}{c}\text { (leggere) un libro } \\
\text { "read a book" } \\
\text { (fare) disegni } \\
\text { "make drawings" } \\
\text { (fare) i compiti la notte } \\
\text { "do homework at night" } \\
\text { (scrivere) un racconto } \\
\text { "write a novel" } \\
\text { (giocare) a calcio } \\
\text { "play football" }\end{array}$ & $\begin{array}{l}\text { (andare) a scuola in bicicletta } \\
\text { "bike to school" } \\
\text { (andare) al cinema } \\
\text { "go to the cinema" } \\
\text { (finire) i compiti presto } \\
\text { "do homework early" } \\
\text { (alzarsi) presto } \\
\text { "wake up early" } \\
\text { (arrivare) tardi a scuola } \\
\text { "arrive late at school" } \\
\text { (addormentarsi) tardi } \\
\text { "fall asleep late" }\end{array}$ \\
\hline
\end{tabular}

\footnotetext{
${ }^{1}$ Following Salaberry (2008), the lexical aspect of a predicate is compositional, i.e., it is determined by several components, such as internal arguments, external arguments, adjuncts and verb particles, which can easily be responsible for aspectual shifts. In line with McManus (2011, p. 118), essere un incidente "to have an accident" (literally, "to be an accident") is classified as an achievement, and not as a state, due to the noun phrase "accident".
}

\subsection{Sample}

The participants were 25 undergraduate learners of Italian with Swedish as L1, divided into four groups (see Table 3). ${ }^{2}$ First, the researcher contacted instructors of Italian at a Swedish university. Subsequently, the same researcher presented the project to the learners enrolled in different courses, specifying the two learner profiles of interest, namely learners with and without previous knowledge of a Romance language. Participants received oral and written information about the project and the students who wanted to participate gave their written consent. The researcher met the participants online during one session for the group without knowledge of a Romance language and two sessions for the group with knowledge of a Romance language. ${ }^{3}$ They completed the oral retelling story test, an interpretation test in English ${ }^{4}$ and a proficiency test inspired by the C-test format (Klein-Braley 1985, 1997) in Italian (henceforth, C-test). The Italian C-test was a translation of a C-test in Spanish and French (Bardel et al. Forthcoming; Ågren et al. 2021). The C-test in Spanish and French was also completed by the Romance group. The C-tests consisted of two short texts where 62 words had been cut off and learners needed to supply the missing letters of the words.

Participants were divided into two levels according to their results in the Italian C-test: high-proficiency learners obtained a score higher than 49 (i.e., the $80 \%$ of 62 ) while lowproficiency learners scored equally or less than 49 . There is a general correlation between length of studies of Italian on the one hand and the results from the C-test on the other: low-proficiency learners were generally students who had studied Italian for one to three terms while high-proficiency learners had received instruction for longer than four terms. Furthermore, learners were divided according to their knowledge of a Romance language into a non-Romance group $(n=10)$ and a Romance group $(n=15)$. The non-Romance group reported no previous knowledge of a Romance language. 
Table 3 shows the results from the C-test in Italian, the C-test in Romance and the interpretation test in English. The groups are divided according to their proficiency in Italian (low-proficiency learners, high-proficiency learners) and knowledge of a Romance language (non-Romance, Romance).

Table 3. Number of participants (n), Mean score (M), standard deviation (SD) and p-values (p) for the C-test in Italian, the C-test in Romance and the English Interpretation Test (EIT).

\begin{tabular}{|c|c|c|c|c|c|c|c|c|c|c|c|c|c|}
\hline & & \multicolumn{4}{|c|}{ C-Test Italian } & \multicolumn{4}{|c|}{ C-Test Romance } & \multicolumn{4}{|c|}{ EIT } \\
\hline & & $n$ & $\mathbf{M}$ & SD & $p$ & $n$ & $\mathbf{M}$ & SD & $p$ & $n$ & $\mathbf{M}$ & SD & $p$ \\
\hline \multirow{2}{*}{ Low-Proficiency } & Non-Rom & 6 & 40.67 & 6.18 & 0.716 & & & & & 6 & 15.33 & 3.09 & 0.481 \\
\hline & Rom & 7 & 39.43 & 5.8 & & 7 & 51.14 & 6.06 & 0.538 & 7 & 16.57 & 3.02 & \\
\hline \multirow{2}{*}{ High-Proficiency } & Non-Rom & 4 & 59 & 2.74 & 0.515 & & & & & 4 & 19.5 & 2.06 & 0.220 \\
\hline & Rom & 8 & 57.63 & 3.53 & & 8 & 48.25 & 10.65 & & 8 & 17.38 & 2.87 & \\
\hline
\end{tabular}

T-tests were run in order to control whether groups were comparable concerning their proficiency level in Italian, in the Romance language and English aspectual knowledge. Starting with the C-test in Italian, the intent was to control that the Romance group was comparable to the non-Romance group when it came to proficiency in Italian. This was the case since no statistically significant differences were found between the Romance and the non-Romance group ( $p=0.716$ for low-proficiency learners; $p=0.515$ for high-proficiency learners). As shown in Table 3, there were differences in number of participants in each group: this was especially problematic for the non-Romance group with high proficiency in Italian, including only four participants. The C-test in Romance languages was intended to control that the Romance group's proficiency in the additional Romance language was similar among low-proficiency and high-proficiency learners. This held true as no significant difference ( $p=0.538$ ) was found between low-proficiency and high-proficiency learners of Italian regarding their proficiency level in the Romance language. Finally, no significant differences were found between the Romance group and the non-Romance group as for English aspectual knowledge ( $p=0.481$ for low-proficiency learners; $p=0.220$ for high-proficiency learners).

\subsection{Analysis of the Data}

An analysis was performed on the verb forms produced by the learners. This was done according to a functionalist view on language as a system of form-function mappings, where the grammatical forms produced by the learners are used in order to express a specific function (Ellis and Barkhuizen 2005, p. 211). Functional analyses conducted on past tense reference can have two different foci. In form-oriented approaches, the departure point for the analysis is the formal realization of a meaning. For example, in form-oriented analyses, instances of passato prossimo can be examined and contrasted with instances of imperfetto. Instead, in meaning-oriented approaches, the function proper is the focus of the analysis, as the concept of 'past', and the different devices employed to express the function are observed (Bardovi-Harlig 2000, pp. 10-11).

Since the past tense forms produced by learners are the departure point of the analysis, a form-oriented functional analysis was carried out, with the objective of understanding what forms learners adopt in specific aspectual contexts elicited in the test.

\section{Results}

The results are divided into two sections, each presenting a proficiency group: lowproficiency (Section 6.1) and high-proficiency (Section 6.2) learners. Within each section, the results are presented for the Romance and the non-Romance group, separately, and for lexical aspect. Since the focus of the study is the use of passato prossimo and imperfetto, each section is concluded by a short summary focusing on these two tenses and excluding the occurrences of the present tense and other tenses. 
The dependent variable is represented by the number of occurrences and percentage of chosen tenses (i.e., passato prossimo, imperfetto, present, other) in each of the two contexts elicited in the oral retelling story test (i.e., perfective, imperfective habitual). Overall, 988 verb forms were analyzed but 29 verb forms were excluded from the analysis, as they were comments produced independently of the context of reference (perfective, imperfective habitual). Therefore, the analysis is based on 959 verb forms. In the analysis, the focus is on the passato prossimo $(n=537)$ and the imperfetto $(n=289)$, which are the most frequent forms produced by the learners. Also, occurrences of the present tense ${ }^{5}$ $(n=67)$ and other forms ${ }^{6}(n=66)$ are reported to provide an overview of all the tenses employed by the learners but they are not the focus of the study. Although the selection of TA morphology is not always straightforward, a rule of thumb for understanding the results is that the perfective context in the narrative should trigger the passato prossimo while the imperfective habitual context should elicit the selection of the imperfetto.

\subsection{Low-Proficiency Learners}

Table 4 shows the number of occurrences and the percentage of tenses employed in perfective contexts by low-proficiency learners divided according to their knowledge of a Romance language and the verbs' lexical aspect.

Table 4. Number of occurrences $(n)$ and percentage (\%) of tenses employed by low-proficiency learners in perfective contexts.

\begin{tabular}{ccccccc}
\hline & \multicolumn{2}{c}{ Non-Romance } & \multicolumn{2}{c}{ Romance } & \multicolumn{2}{c}{ Total } \\
\hline & $\boldsymbol{n}$ & $\mathbf{0}$ & $\boldsymbol{n}$ & $\mathbf{\%}$ & $\boldsymbol{n}$ & $\mathbf{\%}$ \\
\hline Passato prossimo & $\mathbf{8 8}$ & $\mathbf{7 7 . 8 8} \%$ & $\mathbf{8 8}$ & $\mathbf{6 5 . 6 7 \%}$ & $\mathbf{1 7 6}$ & $\mathbf{7 1 . 2 6} \%$ \\
activity & 40 & $35.40 \%$ & 44 & $32.84 \%$ & 84 & $34.01 \%$ \\
stative & 8 & $7.08 \%$ & 9 & $6.72 \%$ & 17 & $6.88 \%$ \\
telic & 40 & $35.40 \%$ & 35 & $26.12 \%$ & 75 & $30.36 \%$ \\
Imperfetto & $\mathbf{3}$ & $\mathbf{2 . 6 5} \%$ & $\mathbf{2 5}$ & $\mathbf{1 8 . 6 6 \%}$ & $\mathbf{2 8}$ & $\mathbf{1 1 . 3 4 \%}$ \\
activity & 1 & $0.88 \%$ & 6 & $4.48 \%$ & 7 & $2.83 \%$ \\
stative & 1 & $0.88 \%$ & 12 & $8.96 \%$ & 13 & $5.26 \%$ \\
telic & 1 & $0.88 \%$ & 7 & $5.22 \%$ & 8 & $3.24 \%$ \\
Present & $\mathbf{1 1}$ & $\mathbf{9 . 7 3} \%$ & $\mathbf{9}$ & $\mathbf{6 . 7 2} \%$ & $\mathbf{2 0}$ & $\mathbf{8 . 1 0} \%$ \\
activity & 1 & $0.88 \%$ & 1 & $0.75 \%$ & 2 & $0.81 \%$ \\
stative & 6 & $5.31 \%$ & 7 & $5.22 \%$ & 13 & $5.26 \%$ \\
telic & 4 & $3.54 \%$ & 1 & $0.75 \%$ & 5 & $2.02 \%$ \\
Other & $\mathbf{1 1}$ & $\mathbf{9 . 7 3} \%$ & $\mathbf{1 2}$ & $\mathbf{8 . 9 6 \%}$ & $\mathbf{2 3}$ & $\mathbf{9 . 3 1 \%}$ \\
activity & 3 & $2.65 \%$ & 4 & $2.99 \%$ & 7 & $2.83 \%$ \\
stative & 2 & $1.77 \%$ & 1 & $0.75 \%$ & 3 & $1.21 \%$ \\
telic & 6 & $5.31 \%$ & 7 & $5.22 \%$ & 13 & $5.26 \%$ \\
Total & $\mathbf{1 1 3}$ & $\mathbf{1 0 0} \%$ & $\mathbf{1 3 4}$ & $\mathbf{1 0 0} \%$ & $\mathbf{2 4 7}$ & $\mathbf{1 0 0} \%$ \\
\hline
\end{tabular}

The majority of the occurrences produced by the non-Romance group in past perfective contexts are passato prossimo $(77.88 \%)$. The present tense is also supplied but to a lesser extent $(9.73 \%)$, while there are only three occurrences of imperfetto $(2.65 \%)$. The Romance group expresses temporality in past perfective contexts mainly by means of the passato prossimo $(65.67 \%)$, but also through the imperfetto $(18.66 \%)$, and the present $(6.72 \%)$. Both groups employ the passato prossimo with all verb categories. The Romance group produces the imperfetto with all verb categories but there is a clear preference for states $(n=12)$. The three occurrences of imperfetto produced by the non-Romance group are spread across verb categories. The present tense is mostly associated to states by both groups.

Table 5 shows the occurrences and the percentage of tenses employed in habitual contexts by low-proficiency learners divided according to their knowledge of a Romance language. 
Table 5. Number of occurrences $(n)$ and percentage (\%) of tenses employed by low-proficiency learners in habitual contexts.

\begin{tabular}{|c|c|c|c|c|c|c|}
\hline & \multicolumn{2}{|c|}{ Non-Romance } & \multicolumn{2}{|c|}{ Romance } & \multicolumn{2}{|c|}{ Total } \\
\hline & $n$ & $\%$ & $n$ & $\%$ & $n$ & $\%$ \\
\hline Passato prossimo & 59 & $67.05 \%$ & 62 & $60.78 \%$ & 121 & $63.68 \%$ \\
\hline activity & 25 & $28.41 \%$ & 26 & $25.49 \%$ & 51 & $26.84 \%$ \\
\hline stative & 5 & $5.68 \%$ & 6 & $5.88 \%$ & 11 & $5.79 \%$ \\
\hline telic & 29 & $32.95 \%$ & 30 & $29.41 \%$ & 59 & $31.05 \%$ \\
\hline Imperfetto & 17 & $19.32 \%$ & 28 & $27.45 \%$ & 45 & $23.68 \%$ \\
\hline activity & 5 & $5.68 \%$ & 8 & $7.84 \%$ & 13 & $6.84 \%$ \\
\hline stative & 6 & $6.82 \%$ & 15 & $14.71 \%$ & 21 & $11.05 \%$ \\
\hline telic & 6 & $6.82 \%$ & 5 & $4.90 \%$ & 11 & $5.79 \%$ \\
\hline Present & 10 & $11.36 \%$ & 4 & $3.92 \%$ & 14 & $7.37 \%$ \\
\hline activity & & $0.00 \%$ & 3 & $2.94 \%$ & 3 & $1.58 \%$ \\
\hline stative & 9 & $10.23 \%$ & 1 & $0.98 \%$ & 10 & $5.26 \%$ \\
\hline telic & 1 & $1.14 \%$ & & $0.00 \%$ & 1 & $0.53 \%$ \\
\hline Other & 2 & $2.27 \%$ & 8 & $7.84 \%$ & 10 & $5.26 \%$ \\
\hline activity & & $0.00 \%$ & 1 & $0.98 \%$ & 1 & $0.53 \%$ \\
\hline telic & 2 & $2.27 \%$ & 7 & $6.86 \%$ & 9 & $4.74 \%$ \\
\hline Total & 88 & $100 \%$ & 102 & $100 \%$ & 190 & $100 \%$ \\
\hline
\end{tabular}

The non-Romance group supplies the majority of past habitual contexts by means of the passato prossimo (67.05\%). The group also employs the imperfetto but to a comparatively limited extent $(19.32 \%)$. Finally, the present tense is employed by this group $(11.36 \%)$. The passato prossimo is also the most common form supplied by the Romance group to express past habitual temporality $(60.78 \%)$, but the imperfetto is also employed to a quite high extent $(27.45 \%)$ while there is a very limited use of the present $(3.92 \%)$.

The imperfetto is evenly distributed across verb classes for the non-Romance group, but there is a preference in the Romance group to select the imperfetto with states (14.71\%). The passato prossimo is mainly expressed with dynamic predicates by both groups. Nine times out of ten, the present is associated with a state in the non-Romance group, while the Romance group has three activities and one state expressed in the present.

Since the focus is on the use of passato prossimo and imperfetto, Figure 1 shows the use of these two tenses made by low-proficiency learners in perfective and habitual contexts according to lexical aspect.

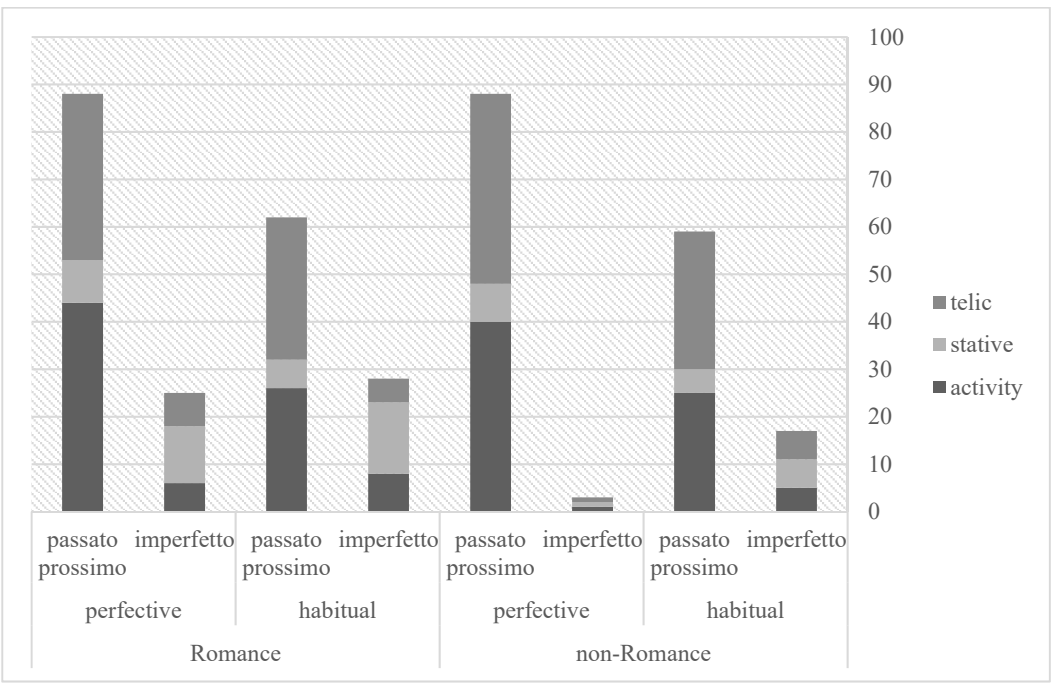

Figure 1. Number of occurrences of passato prossimo and imperfetto in perfective and habitual contexts produced by low-proficiency learners according to lexical aspect (telic, stative, activity) and knowledge of a Romance language L2 (Romance, non-Romance). 
To summarize, both groups prefer the passato prossimo in perfective contexts, although the Romance group also includes the imperfetto, showing a preference for states. As for habitual contexts, both groups overuse the passato prossimo. However, while the Romance group employs the passato prossimo twice as much as the imperfetto ( $60.78 \%$ vis-à-vis $27.45 \%)$, the non-Romance group supplies the passato prossimo $(67.05 \%)$ almost four times more than the imperfetto (19.32\%). The Romance group also tends to inflect states in the imperfetto, while the non-Romance group uses it with all verb categories.

\subsection{High-Proficiency Learners}

Table 6 shows the number of occurrences and the percentage of tenses employed in perfective contexts by the high-proficiency group divided according to their knowledge of a Romance language and lexical aspect.

Table 6. Number of occurrences $(n)$ and percentage (\%) of tenses employed by high-proficiency learners in perfective contexts.

\begin{tabular}{ccccccc}
\hline & \multicolumn{2}{c}{ Non-Romance } & \multicolumn{2}{c}{ Romance } & \multicolumn{2}{c}{ Total } \\
\hline & $\boldsymbol{n}$ & $\mathbf{\%}$ & $\boldsymbol{n}$ & $\mathbf{\%}$ & $\boldsymbol{n}$ & $\mathbf{\%}$ \\
\hline Passato prossimo & $\mathbf{6 9}$ & $\mathbf{6 7 . 6 5 \%}$ & $\mathbf{1 5 4}$ & $\mathbf{7 0 . 6 4 \%}$ & $\mathbf{2 2 3}$ & $\mathbf{6 9 . 6 9 \%}$ \\
activity & 19 & $18.63 \%$ & 53 & $24.31 \%$ & 72 & $22.50 \%$ \\
stative & 3 & $2.94 \%$ & 19 & $8.72 \%$ & 22 & $6.88 \%$ \\
telic & 47 & $46.08 \%$ & 82 & $37.61 \%$ & 129 & $40.31 \%$ \\
Imperfetto & $\mathbf{2 2}$ & $\mathbf{2 1 . 5 7 \%}$ & $\mathbf{2 1}$ & $\mathbf{9 . 6 3} \%$ & $\mathbf{4 3}$ & $\mathbf{1 3 . 4 4 \%}$ \\
activity & 8 & $7.84 \%$ & 6 & $2.75 \%$ & 14 & $4.38 \%$ \\
stative & 10 & $9.80 \%$ & 12 & $5.50 \%$ & 22 & $6.88 \%$ \\
telic & 4 & $3.92 \%$ & 3 & $1.38 \%$ & 7 & $2.19 \%$ \\
Present & $\mathbf{4}$ & $\mathbf{3 . 9 2} \%$ & $\mathbf{2 2}$ & $\mathbf{1 0 . 0 9 \%}$ & $\mathbf{2 6}$ & $\mathbf{8 . 1 3} \%$ \\
activity & & $0.00 \%$ & 1 & $0.46 \%$ & 1 & $0.31 \%$ \\
stative & 3 & $2.94 \%$ & 18 & $8.26 \%$ & 21 & $6.56 \%$ \\
telic & 1 & $0.98 \%$ & 3 & $1.38 \%$ & 4 & $1.25 \%$ \\
Other & $\mathbf{7}$ & $\mathbf{6 . 8 6 \%}$ & $\mathbf{2 1}$ & $\mathbf{9 . 6 3} \%$ & $\mathbf{2 8}$ & $\mathbf{8 . 7 5 \%}$ \\
activity & 4 & $3.92 \%$ & 10 & $4.59 \%$ & 14 & $4.38 \%$ \\
stative & 1 & $0.98 \%$ & 4 & $1.83 \%$ & 5 & $1.56 \%$ \\
telic & 2 & $1.96 \%$ & 7 & $3.21 \%$ & 9 & $2.81 \%$ \\
Total & $\mathbf{1 0 2}$ & $\mathbf{1 0 0} \%$ & $\mathbf{2 1 8}$ & $\mathbf{1 0 0} \%$ & $\mathbf{3 2 0}$ & $\mathbf{1 0 0} \%$ \\
\hline
\end{tabular}

The non-Romance group primarily employs the passato prossimo $(67.65 \%)$ in order to express a concluded situation in the past. They make quite an extensive use of the imperfetto $(21.57 \%)$ while the present tense is used in a limited way $(3.92 \%)$. The Romance group mainly expresses past perfective contexts through the passato prossimo $(70.64 \%)$. Also, past perfective situations are expressed through the imperfetto $(9.63 \%)$ and the present $(10.09 \%)$.

As for aspectual classes, both groups display preferences in employing the passato prossimo with dynamic predicates, mostly with telic predicates. This tendency is particularly evident for the non-Romance group. On the one hand, the non-Romance group employs the passato prossimo with states only in three out of 69 occurrences. A similar, but much less prevalent, trend is displayed by the Romance group, as they produce 19 states out of 154 instances of passato prossimo. On the other hand, states represent the most-frequently employed verb category with the imperfetto by both groups, ten of 22 occurrences for the non-Romance group and 12 out of 21 for the Romance group.

Table 7 presents the occurrences and the percentage of tenses employed in habitual contexts by high-proficiency learners divided according to their knowledge of a Romance language. 
Table 7. Number of occurrences $(n)$ and percentage (\%) of tenses employed by high-proficiency learners in habitual contexts.

\begin{tabular}{|c|c|c|c|c|c|c|}
\hline & \multicolumn{2}{|c|}{ Non-Romance } & \multicolumn{2}{|c|}{ Romance } & \multicolumn{2}{|c|}{ Total } \\
\hline & $n$ & $\%$ & $n$ & $\%$ & $n$ & $\%$ \\
\hline Passato prossimo & 3 & $5.17 \%$ & 14 & $9.72 \%$ & 17 & $8.42 \%$ \\
\hline stative & & $0.00 \%$ & 5 & $3.47 \%$ & 5 & $2.48 \%$ \\
\hline telic & 3 & $5.17 \%$ & 9 & $6.25 \%$ & 12 & $5.94 \%$ \\
\hline Imperfetto & 52 & $89.66 \%$ & 121 & $84.03 \%$ & 173 & $85.64 \%$ \\
\hline activity & 19 & $32.76 \%$ & 45 & $31.25 \%$ & 64 & $31.68 \%$ \\
\hline stative & 9 & $15.52 \%$ & 33 & $22.92 \%$ & 42 & $20.79 \%$ \\
\hline telic & 24 & $41.38 \%$ & 43 & $29.86 \%$ & 67 & $33.17 \%$ \\
\hline Present & 1 & $1.72 \%$ & 6 & $4.17 \%$ & 7 & $3.47 \%$ \\
\hline stative & 1 & $1.72 \%$ & 4 & $2.78 \%$ & 5 & $2.48 \%$ \\
\hline telic & & $0.00 \%$ & 2 & $1.39 \%$ & 2 & $0.99 \%$ \\
\hline Other & 2 & $3.45 \%$ & 3 & $2.08 \%$ & 5 & $2.48 \%$ \\
\hline activity & 1 & $1.72 \%$ & & $0.00 \%$ & 1 & $0.50 \%$ \\
\hline telic & 1 & $1.72 \%$ & 3 & $2.08 \%$ & 4 & $1.98 \%$ \\
\hline Total & 58 & $100 \%$ & 144 & $100 \%$ & 202 & $100 \%$ \\
\hline
\end{tabular}

Almost all the verbs produced by the non-Romance group are inflected in the imperfetto $(89.66 \%)$, while there are three occurrences of passato prossimo and one occurrence of the present. A similar trend is evident in the Romance group, expressing past habituality mainly through the imperfetto $(84.03 \%)$ and in a limited way through the passato prossimo $(9.72 \%)$ and the present $(4.17 \%)$. Both groups employ the imperfetto with all types of predicates. However, when the passato prossimo is supplied in habitual contexts, it is produced with telic verbs. These predicates make up for all three occurrences of passato prossimo produced in the non-Romance group and for nine of the 14 occurrences of passato prossimo in the Romance group.

Figure 2 shows the use of passato prossimo and imperfetto made by high-proficiency learners in perfective and habitual contexts according to lexical aspect.

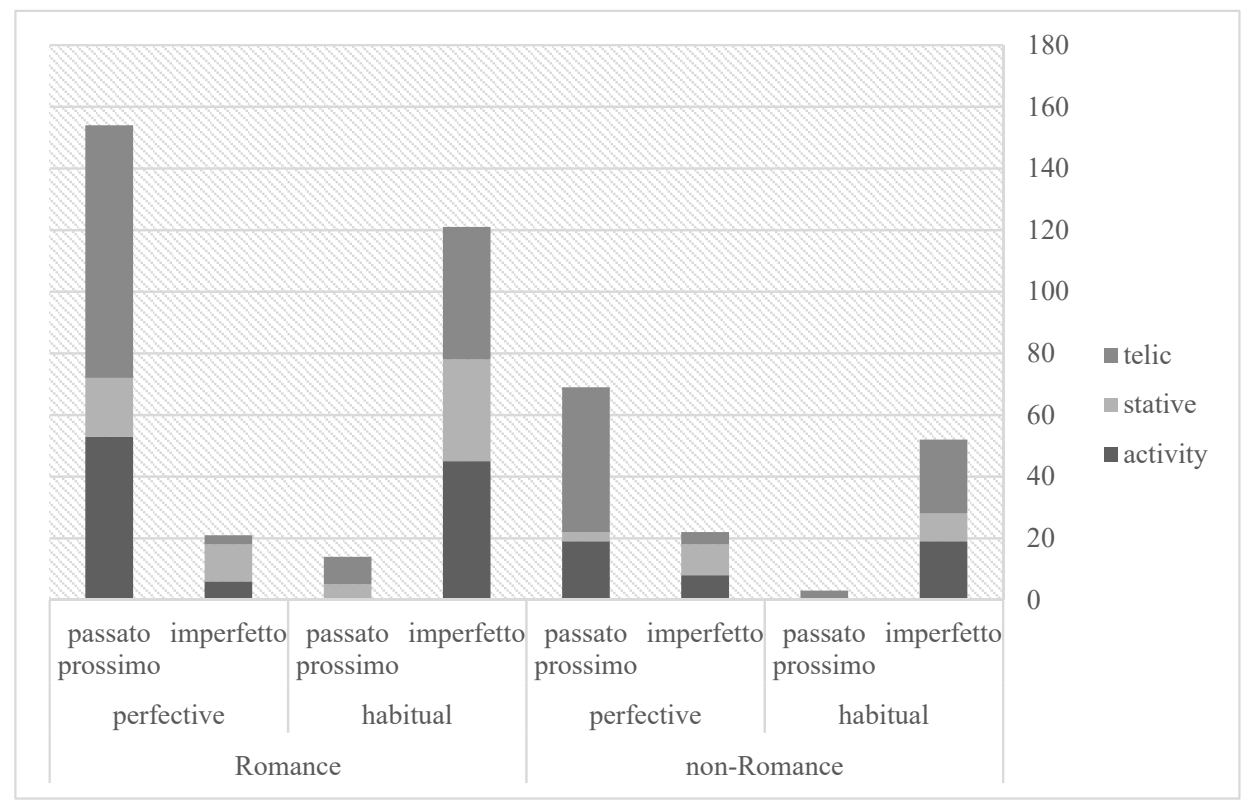

Figure 2. Number of occurrences of passato prossimo and imperfetto in perfective and habitual contexts produced by high-proficiency learners according to lexical aspect (telic, stative, activity) and knowledge of a Romance language L2 (Romance, non-Romance). 
To sum up, the passato prossimo is largely employed by both groups in perfective contexts, but the non-Romance group is reluctant to employ it with states. Furthermore, the non-Romance group makes extensive use of the imperfetto with atelic predicates-both states and activities-while the Romance group uses the imperfetto to a lesser extent and, when they do so, it is mostly with states. Regarding habitual contexts, both groups use predominantly the imperfetto and they do so with all verb types. The passato prossimo is employed to a very limited extent in habitual contexts, and almost exclusively with telic predicates.

\section{Discussion and Conclusions}

The present study addressed potential differences in how L1 Swedish speakers learning Italian at different proficiency levels express TA morphology depending on whether or not they have knowledge of a Romance L2, i.e., the typology factor, and on the inherent lexical aspect of the predicates, i.e., the prototype factor. In the discussion, each proficiency group is presented separately.

Let us first consider low-proficiency learners. The passato prossimo is the most commonly employed form to express past reference by the Romance and the non-Romance low-proficiency groups while the imperfetto is used to a more limited extent, which is in line with previous studies on the acquisition of L2 Italian (Giacalone Ramat 1990, 2002). Both low-proficiency groups employ the passato prossimo with all verb types, which corroborates the tenets of the DPTH (Salaberry 2000, 2008; Wiberg 1996). In fact, they seem to initially express past temporality, but not aspect, through the passato prossimo. According to the DPTH (Salaberry 2000, 2008; Wiberg 1996), the first distinction made by L2 learners is partly due to the L1 influence, as learners whose L1 lacks aspectual contrasts in the past, as English or Swedish, tend to consider Romance tenses as temporal markers only. In our case, L1 Swedish speakers initially fall back on the temporal distinction existing in their L1 and equate the preteritum with the passato prossimo.

Considering the imperfetto, the low-proficiency non-Romance group produces it with all types of predicates, in a way similar to their use of the passato prossimo. The absence of restrictions to specific lexical classes casts a doubt on whether learners in the lowproficiency non-Romance group have properly grasped the habitual meaning expressed by the Italian imperfetto. Possibly, the emergence of the imperfetto in the interlanguage of low-proficiency learners in the non-Romance group may, as well as for the passato prossimo, reflect a temporal contrast rather than an aspectual contrast. When the choice between passato prossimo and imperfetto is made, it could refer to recent and remote events in the past, respectively. Introspective data from learners in the same sample without knowledge of a Romance language (Vallerossa 2021) appear to corroborate this hypothesis, as in the comment:

Pp passar inte eftersom det är en avslutad händelse för länge sedan. Dåtid så sent som igår, alltså pp. Imperfetto skulle indikera längre förfluten tid. 'Pp (passato prossimo) does not work because it is a completed event long ago. Past as late as yesterday, which is pp. Imperfetto would indicate more distant past time'.

The low-proficiency Romance group uses the imperfetto more consistently than the low-proficiency non-Romance group. This trend is noticeable for both perfective and habitual contexts, where the low-proficiency Romance group makes a comparatively larger use of the imperfetto than the low-proficiency non-Romance group (for perfective contexts, $18.66 \%$ vis-à-vis 2.65\%; for habitual contexts, $27.45 \%$ vis-à-vis $19.32 \%$ ). More importantly, the imperfetto is consistently used by the low-proficiency Romance group with states in both perfective $(n=12)$ and habitual $(n=15)$ contexts. Hence, comparing the use of the imperfetto made by low-proficiency learners, the interlanguage of the Romance group is more influenced by the prototype factor than the non-Romance group. This reflects previous studies conducted in the light of the LAH, showing that the contrast between dynamic predicates and states orients the choice of perfective and imperfective inflectional 
morphology made by L1 English speakers learning French (Bergström 1995) or Spanish (Domínguez et al. 2013; González and Hernández 2018).

Moving to the high-proficiency learners, they display similar trends regardless of knowing a Romance language or not. Overall, the distribution of passato prossimo in perfective contexts and imperfetto in habitual contexts is rather homogeneous in the highproficiency groups. There are, however, some differences in their use of tenses.

Let us first consider perfective contexts. In these contexts, the high-proficiency Romance group employs the passato prossimo with all verb types while the high-proficiency non-Romance group tends to select the passato prossimo with dynamic predicates and the imperfetto with states. This selective pattern for the high-proficiency non-Romance group is worth commenting on. States are well-known to be particularly troublesome for learners in relation with perfective morphology. This is due to a combination of both a negative influence from the L1 (see Salaberry 2005) and semantic principles, such as the Relevance Principle and the Congruence Principle (Andersen 1993). As for the L1, Salaberry (2005) maintains that there is an inherently different way in how L1 English speakers acquire states vis-à-vis dynamic verbs. In English, dynamic predicates occur in both Simple Past and Progressive Past, unlike states that are usually inflected in the Simple Past. In Swedish as well, there exists a similar discrepancy in how different verb types are marked. Like L1 English-speaking learners, this would make L1 Swedish-speaking learners more conservative in employing only one tense form to mark states in Romance languages. Further, the consistent preference of imperfective morphology with states reflects semantic principles (see Andersen 1993 for the Congruence Principle): the proximity between grammatical aspect (i.e., the notion of indefiniteness expressed by the imperfective past tense) and stativity (i.e., the expression of a stable, unmodified condition) is undoubtedly responsible for the large amount of these prototypical associations (Giacalone Ramat 1990, 2002). The differential path of acquisition proposed by Salaberry (2005), which is determined by a persisting negative L1 influence, seems to operate for our high-proficiency learners, but only for the non-Romance group. Knowledge of a Romance language, combined with high proficiency in the TL, seems to provide an advantage to the high-proficiency Romance group in that they adhere less consistently to prototypes. Instead, the high-proficiency Romance group is able to produce states with the passato prossimo.

Further, there is an overextension of the imperfetto in perfective contexts by the highproficiency non-Romance group $(21.57 \%)$. This overuse of the imperfetto is similar to the one made by the low-proficiency group with knowledge of a Romance language. This result can be connected to the fact that the imperfetto may be a recently discovered form in the interlanguage of both these learner groups. When learners first discover a new form, they tend to temporarily overextend it, prior to moving towards a more target-like use (Kihlstedt 2002, p. 342).

While there are differences for perfective contexts, both high-proficiency groups display similar tendencies for habitual contexts. In fact, both the Romance and the nonRomance groups with high proficiency in Italian consistently select the imperfetto (84.03\% and $89.66 \%$, respectively), and do so with all verb types, suggesting that they have acquired the imperfetto and are able to express past habituality regardless of verb type.

If comparing low-proficiency learners and high-proficiency learners, our data show differential patterns determined by the prototype factor and the typology factor. The latter has to be understood in relative terms with reference to the TL: in our case, there is typological distance between the L1 Swedish and Italian, and typological proximity between the L2 Romance language and Italian.

For low-proficiency learners without knowledge of a Romance language, the typological distance between the L1 and Italian determines the absence of restrictions to specific lexical aspect classes in the use of Italian past tenses. Instead, the use of imperfetto and passato prossimo is likely to reflect a temporal difference between remote events and general past events, which is believed to be due to negative transfer from Swedish. Conversely, our data suggest that having additional knowledge of a Romance language when approaching 
a new Romance language translates into two features. First, it accelerates the overall emergence of the imperfetto. Second, it makes learners with knowledge of a Romance language more sensitive to aspectual contrasts, as they are more prone to select the imperfetto according to the semantics of the predicates, i.e., according to prototypes. Indeed, the fact that the low-proficiency Romance group produces combinations of imperfetto and states suggests that these learners have grasped the aspectual meanings connected to the imperfetto. Arguably, both these features in the interlanguage of the low-proficiency Romance group are connected to a high level of cross-linguistic awareness, namely the ability to detect similarities and differences between languages (Jessner 2006, p. 116). In fact, these learners are likely to exploit their cross-linguistic awareness to draw comparisons with a corresponding imperfective tense form in French (imparfait) or Spanish (imperfecto), and, consequently, to transfer this type of knowledge to Italian (see Bardel 2005; Salaberry 2005).

At advanced stages, knowledge of a Romance language allows learners to move past prototypes with the passato prossimo. While the high-proficiency Romance group eventually acquires the passato prossimo and the imperfetto with all verb types, the high-proficiency non-Romance group seems to consistently rely on prototypes for the passato prossimo. Seemingly, this reliance on prototypes when inflecting the passato prossimo precedes the use of the passato prossimo as an aspectual marker regardless of verb types, which is the pattern displayed by the high-proficiency Romance group. More importantly, this finding would provide evidence for a persisting positive L2 influence from a Romance language at advanced stages.

Finally, it is crucial to relate our findings to previous studies on Ln learning in general and on the Ln acquisition of aspectual contrasts in Romance languages in particular. We found positive effects of knowledge of a L2 Romance language among both low-proficiency learners and high-proficiency learners. The former result is congruent with research on Ln learning showing that some L2-related influences are more prevalent during the initial stages of appropriation of an Ln (see for example Bardel 2015; Bardel and Lindqvist 2007). Intuitively, the influence from previously learnt languages is stronger when the grammar of the TL is yet to be fully developed; therefore, learners are likely to fall back on their L2s to bridge knowledge gaps in the TL. As TL proficiency increases, the learners' interlanguage progressively stabilizes. That is, the space previously occupied by other learnt languages is subsequently filled in concomitance with increased TL proficiency. However, we also found evidence for a persisting positive L2 influence at more advanced stages. More specifically, it seems as if knowledge of a L2 Romance language speeds up certain developmental stages characterized by a reliance on prototypes. In fact, knowing a Romance language helps learners appropriate the entire array of combinations of verb types and past tenses more rapidly than their peers without knowledge of a Romance language. Crucially, this would partly contradict previous studies postulating a differential learning path for prototypical and non-prototypical associations (see Diaubalick et al. 2020; Salaberry 2005, 2020; Vallerossa et al. Forthcoming). Unlike these studies, our data suggest that both types of associations are ultimately acquirable and that L2 knowledge is transferable not only for prototypical but also for non-prototypical associations. Undoubtedly, the role exerted by previous language knowledge at more advanced stages represents a promising point of departure for future studies on aspect.

There are, however, a few remarks that need to be acknowledged. First, the overall findings need to be cautiously interpreted in the light of the limited number of learners. This is especially problematic for our results connected to the high-proficiency group without knowledge of a Romance language, in which there were only four learners. Our main finding for this learner group, namely the persistent negative L1 influence, needs therefore to be tested with a larger learner sample of high-proficiency learners without additional knowledge of a Romance language. ${ }^{7}$ Future research may ideally draw on data from more consistent learner groups, in order to test clearly formulated hypotheses and allow for the generalizability of the results. However, given the multifaceted prior language knowledge of multilingual learners (varying number of background languages, varying 
degree of proficiency in these languages, as well as variation in their typological proximity to the TL), Ln data are known to be notoriously messy (Falk and Bardel 2021). Furthermore, in addition to being very demanding, such a rigorous practice is not free from limitations. In fact, recruiting a consistent pool of learners based on whether they meet specific criteria necessarily implies the exclusion of a large portion of learners. This type of selective procedure severely undermines the ecological validity of a study, especially in those studies investigating learners with extremely heterogeneous multilingual backgrounds, as is the case of undergraduate studies of Italian in Sweden. The dilemma of whether privileging generalizability over ecological validity is one of several methodological issues that is currently under discussion in research on Ln learning. Balancing both needs is however very difficult and such ambitions fall clearly beyond the aim of the present study, which is explorative in its nature. In fact, we wanted to display viable ways of understanding what being multilingual may imply when approaching aspectual contrasts in Romance, rather than juxtaposing models of Ln learning, which would require a different setup (see for example Vallerossa and Bardel Forthcoming). Second, a methodological remark is necessary for the abovementioned hypothesis about the use of passato prossimo and imperfetto as temporal markers for the low-proficiency non-Romance group. Future studies have to employ tasks where the notions of remoteness and habituality do not overlap. In fact, the excerpt used in the present study to elicit the imperfetto presents a habitual situation located in a remote past. Therefore, it is difficult to ascertain whether learners without knowledge of a Romance language used the imperfetto as an aspectual marker for habituality or as a temporal marker for remoteness. Finally, we controlled for English aspectual knowledge, understood as the contrast between Simple Past and Progressive Past. However, it would not be possible to isolate the effect determined by knowledge of English on the aspectual contrasts examined here, namely that between perfective and imperfective habitual. In fact, English, like Swedish, lacks inflectional morphology for habitual aspect, which complicates to ascertain whether English, Swedish, or both contributed to transfer. The realm where English knowledge alone may potentially have a bootstrapping effect is progressive aspect (Eibensteiner 2019; Vallerossa et al. Forthcoming). Furthermore, controlling for aspectual knowledge in Romance, rather than overall proficiency, would allow us to infer whether proper aspectual knowledge from the Romance L2 is transferred to the Romance L3.

To conclude, this study shows that the influence of the typological proximity between the L2 Romance and Italian can be found in both low-proficiency and high-proficiency L1 Swedish speaking learners of Italian. At initial stages, it translates into a premature emergence of the imperfetto, intended as an aspectual marker. At advanced stages, it allows learners to move beyond prototypical associations for the passato prossimo. Crucially, the influence of the prototype factor is stronger in low-proficiency learners with knowledge of a Romance language but diminishes with increased TL proficiency. Conversely, the influence of prototypes persists among high-proficiency learners without knowledge of a Romance L2, who tend to consistently adhere and overproduce associations of passato prossimo and dynamic predicates.

Funding: This project received no external funding.

Institutional Review Board Statement: The study was conducted according to the guidelines of the Declaration of Helsinki, and approved by the Swedish Board of Ethical Review (Regionala etikprözningsnämnden i Stockholm) (2020-00846, approved in June 2020).

Informed Consent Statement: Informed consent was obtained from all subjects involved in the study.

Data Availability Statement: The data presented in this study are available on request from the author. The data are not publicly available due to ethical reasons.

Conflicts of Interest: The author declares no conflict of interest. 


\section{Appendix A}

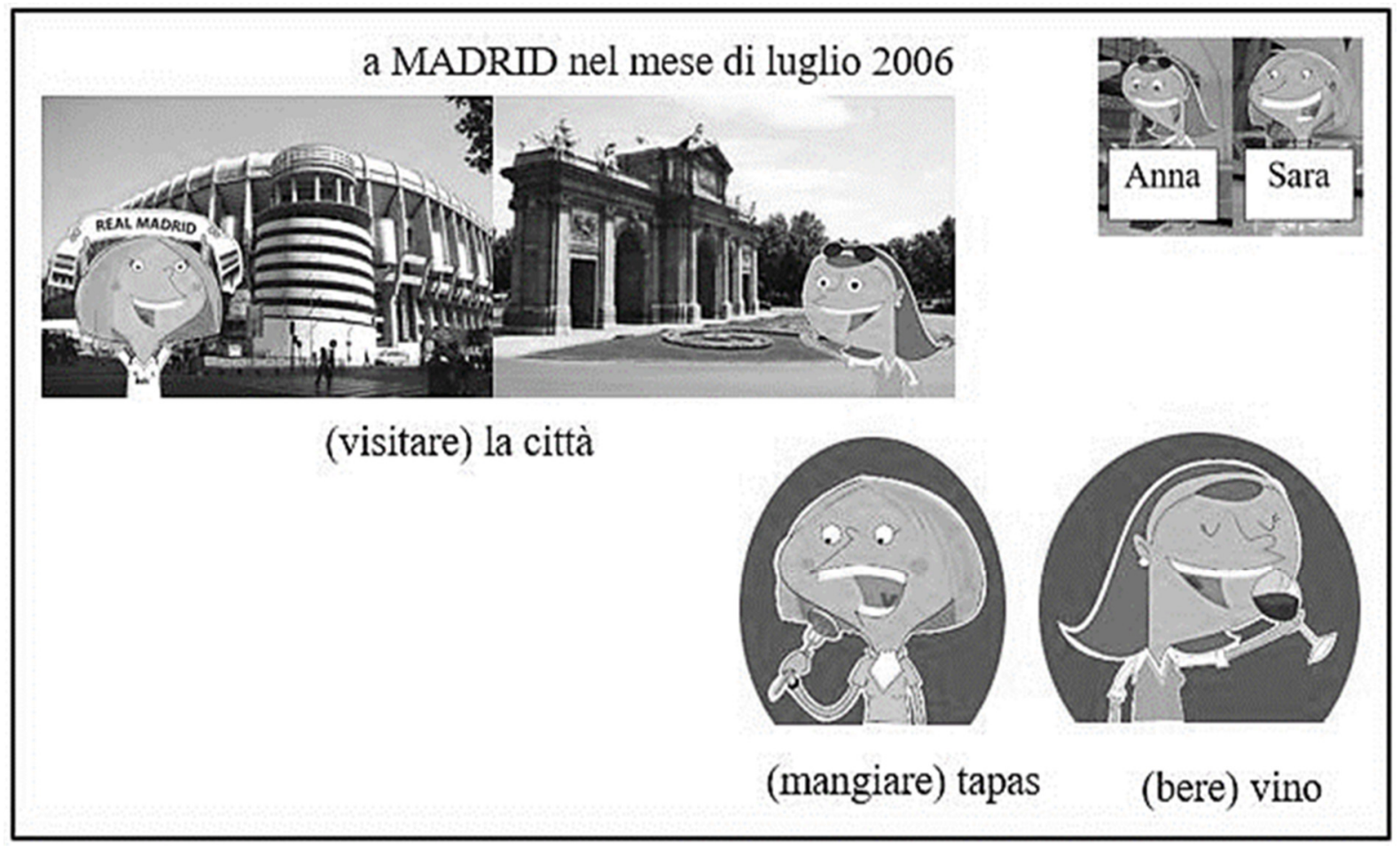

Figure A1. Example of Perfective Context from the "Sisters' Story".

Appendix B

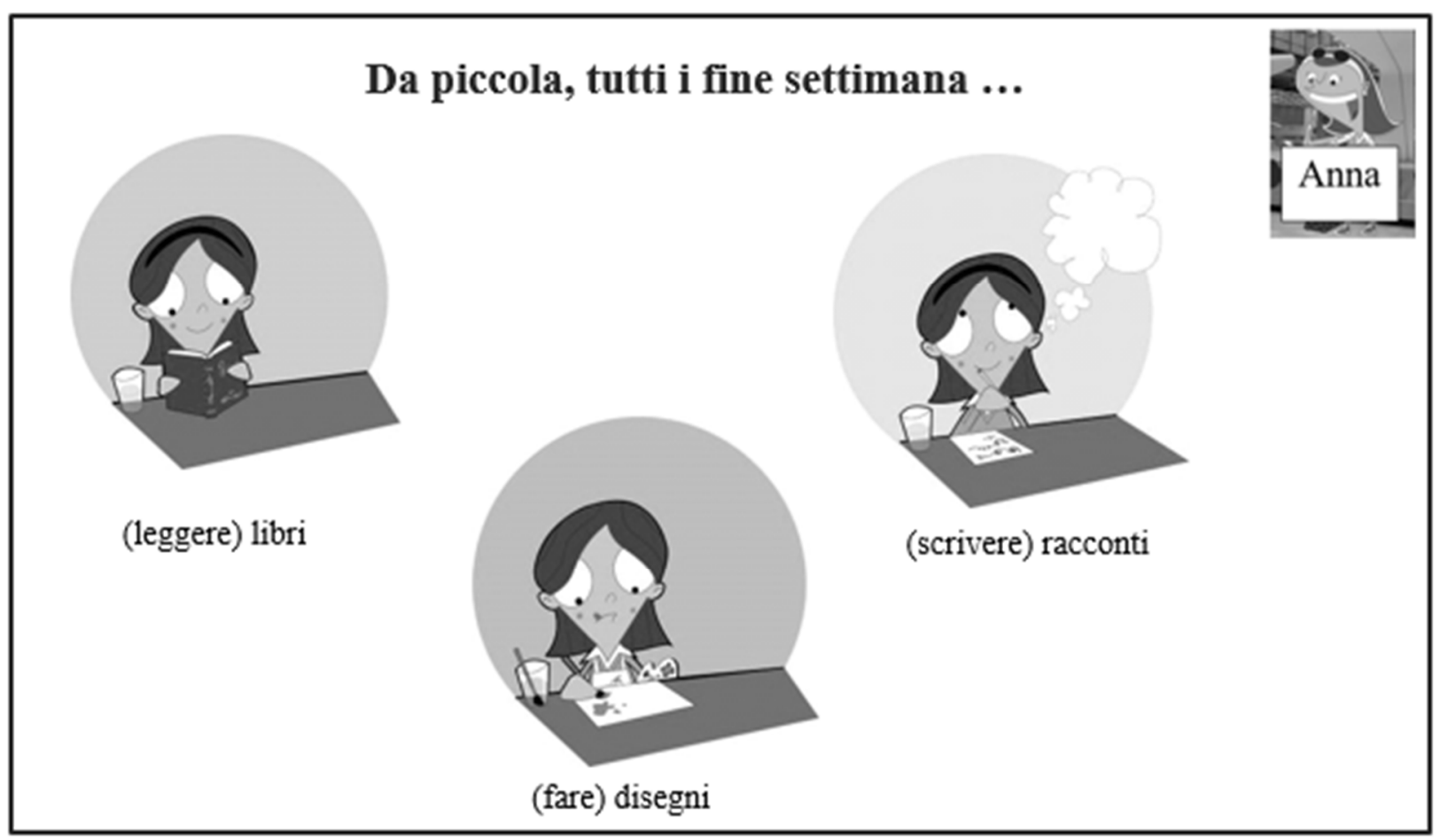

Figure A2. Example of Imperfective Habitual Context from the "Sisters' Story".

\section{Notes}

1 The SPLLOC project aimed to promote research on the acquisition of Spanish as L2 (for more details see www.splloc.soton.ac.uk accessed on 28 October 2021). 
2 Overall, there were 15 female and 10 male participants. Their age ranged from 21 to $76(M=44.7 ; S D=19.47)$. Twenty-one participants were recruited from seven undergraduate courses of Italian. Except for the first two preparatory courses consisting of 15 ECTS each, a full-time course generally spans over a term and consists of 30 ECTS, although some courses are also offered at half-time pace. In Sweden, there are no official guidelines concerning the correspondence between each course and proficiency level according to the Common European Framework for Languages (Council of Europe 2001). However, the most advanced course within undergraduate studies (i.e., Kandidat) implies that the student is able to write a thesis about Italian literature or linguistics. Hence, these skills would approximately be equivalent to the advanced level C1. The distribution of the participants is as follows: five participants were recruited from the first preparatory course of Italian, three from the second preparatory course, four from Italian I, four from Italian II, two from Italian III, two from Italian IV and one from the Bachelor thesis course in Italian (Kandidat). Given the difficulty in recruiting undergraduate students of Italian, the researcher also published an advertisement on social media specifying the inclusion criteria for taking part in the project; four participants responded to the advertisement. They all had knowledge of Swedish and were studying or had recently studied Italian privately or through educational associations (Studieförbund).

3 The majority of the participants completed the retelling story test during an online meeting, which was audio recorded. However, as the oral retelling story test was the last test of a test battery, a few participants had to leave the meeting. Thus, they were allowed to record themselves autonomously and to send the file to the researcher. We are aware that the absence of the researcher when these learners completed the test is problematic. However, the researcher stressed the importance of completing the test in a spontaneous way, and the participants were discouraged to plan or prepare it in advance. Because the recordings showed several traces of hesitation and uncertainty, we believe that the learners followed the instructions. Hence, all the learners were included in the final sample.

4 The English Interpretation Test, adapted from Eibensteiner (2019), aimed to test aspectual knowledge in English, operationalized in terms of the contrast between Simple Past and Progressive Past. The test consisted of 15 tasks, each including a context in Swedish and two target sentences in English. The maximum score of this test was 24. Five tasks elicited perfective contexts, with the Simple Past yielding correct interpretations, while seven tasks elicited progressive contexts, with the Progressive Past yielding correct interpretations. There were three additional distractor tasks. See Vallerossa et al. (Forthcoming) for a detailed description of the English Interpretation Test.

5 It is important to point out that the constructions with the present tense observed in the study are target-like and not used to supply past tense forms not yet acquired by the learners.

6 Other forms produced by the learners are: congiuntivo imperfetto, gerundio, imperativo, infinito, infinito passato, participio passato, passato remoto, the periphrastic construction with stare + gerund and trapassato prossimo. Seven forms, which could not be categorized, were coded as "target-deviant".

7 As pointed out by an anonymous reviewer, the division into subgroups based on proficiency complicates the possibility of making any generalizations, as the number of participants resulting from the grouping criteria is limited. An alternative way would have been that of juxtaposing groups based on their knowledge of a Romance L2, or lack thereof, but disregarding proficiency in Italian. Since learners were recruited from several courses and their proficiency in Italian varied greatly, we decided to control for TL proficiency by dividing the learners into four subgroups.

\section{References}

Ågren, Malin, Camilla Bardel, and Susan Sayehli. 2021. Same or different? Comparing language proficiency in French, German and Spanish in Swedish lower secondary school. Paper presented at the Conference Exploring Language Education (ELE) 2021: Teaching and Learning Languages in the 21st Century, University of Oslo, Oslo, Norway, June 9-11.

Andersen, Roger. 1993. Four operating principles and input distribution as explanation for underdeveloped and mature morphological systems. In Progression and Regression in Language. Edited by Kenneth Hyltenstam and Åke Viberg. Cambridge: Cambridge University Press, pp. 309-39. [CrossRef]

Bardel, Camilla. 2005. L'apprendimento dell'italiano come L3 di un apprendente plurilingue. Il caso del sistema verbale. In Omaggio a/Hommage à/Homenaje a Jane Nystedt [Homage to Jane Nystedt]. Edited by Michael Metzeltin. Wien: Drei Eidechsen, pp. 9-16.

Bardel, Camilla. 2006. DITALS di I e II livello per gli insegnanti di italiano in Svezia. In La DITALS risponde 3. Edited by Pierangela Diadori. Perugia: Guerra Edizioni, pp. 187-90.

Bardel, Camilla. 2015. Lexical cross-linguistic influence in third language development. In Transfer Effects in Multilingual Language Development. Edited by Hagen Peukert. Amsterdam: John Benjamins, pp. 111-28. [CrossRef]

Bardel, Camilla, and Christina Lindqvist. 2007. The role of proficiency and psychotypology in lexical cross-linguistic influence. A study of a multilingual learner of Italian L3. In Atti del VI Congresso Internazionale dell' Associazione Italiana di Linguistica Applicata, Napoli, 9-10 Febbraio 2006. Edited by Marina Chini, Paola Desideri, Maria Elena Favilla and Gabriele Pallotti. Perugia: Guerra Edizioni, pp. 123-45.

Bardel, Camilla, Susan Sayehli, and Malin Ågren. Forthcoming. Developing a C-test for young learners of foreign languages at the A1-A2 level in Sweden. Methodological considerations. Manuscript in preparation.

Bardovi-Harlig, Kathleen. 2000. Tense and Aspect in Second Language Acquisition: Form, Meaning and Use. Oxford: Blackwell. 
Bardovi-Harlig, Kathleen, and Llorenç Comajoan-Colomé. 2020. The aspect hypothesis and the acquisition of L2 past morphology in the last 20 years. A state-of-the-scholarship review. Studies in Second Language Acquisition 42: 1137-67. [CrossRef]

Bergström, Anna. 1995. The Expression of Past Temporal Reference by English speaking Learners of French. Doctoral disstertation, Pennsylvania State University, Pennsylvania, PA, USA.

Blensenius, Kristian. 2013. En pluraktionell progressivmarkör? Hålla på att jämförd med hålla på och. Språk och stil 23: 175-204.

Blyth, Carl. 2005. From Empirical Findings to the Teaching of Aspectual Distinctions. In Tense and Aspect in Romance Languages: Theoretical and Applied Perspectives. Edited by Dalila Ayoun and M. Rafael Salaberry. Amsterdam: John Benjamins, pp. 211-52. [CrossRef]

Collins, Laura. 2002. The roles of L1 influence and lexical aspect in the acquisition of temporal morphology. Language Learning 52: 43-94. [CrossRef]

Comrie, Bernard. 1976. Aspect. Cambridge: Cambridge University Press.

Council of Europe. 2001. Common European Framework of Reference for Languages: Learning, Teaching, Assessment. Cambridge: Cambridge University Press.

Diaubalick, Tim, Lukas Eibensteiner, and M. Rafael Salaberry. 2020. Influence of L1/L2 linguistic knowledge on the acquisition of L3 Spanish past tense morphology among L1 German speakers. International Journal of Multilingualism. [CrossRef]

Domínguez, Laura, Nicole Tracy-Ventura, María J. Arche, Rosamond Mitchell, and Florence Myles. 2013. The role of dynamic contrasts in the L2 acquisition of Spanish past tense morphology. Bilingualism: Language and Cognition 16: 558-77. [CrossRef]

Eibensteiner, Lukas. 2019. Transfer in L3 Acquisition: How does L2 aspectual knowledge in English influence the acquisition of perfective and imperfective aspect in L3 Spanish among German-speaking learners? Dutch Journal of Applied Linguistics 8: 67-83. [CrossRef]

Ellis, Rod, and Gary Barkhuizen. 2005. Analysing Learner Language. Oxford: Oxford University Press.

Falk, Ylva, and Camilla Bardel. 2021. L3 proficiency and development. Some essential methodological considerations. Paper presented at L3-AIS 2021, Virtual Workshop on L3 Development after the Initial State, Boston University, Massachusetts Institute of Technology, and University of Applied Sciences Burgenland, Eisenstadt, Austria, October 1-2.

Foote, Rebecca. 2009. Transfer and L3 acquisition: The role of typology. In Third Language Acquisition and Universal Grammar. Edited by Yan-Kit Ingrid Leung. Clevedon: Multilingual Matters, pp. 89-114.

Giacalone Ramat, Anna. 1990. Presentazione del progetto di Pavia sull'acquisizione di lingue seconde. Lo sviluppo di strutture temporali [Presentation of Pavia project about the acquisition of second languages. The development of temporal structures]. In La temporalità nell'acquisizione delle lingue seconde: Atti del convegno internazionale: Pavia, 28-30 ottobre 1988. Edited by Giuliano Bernini and Anna Giacalone Ramat. Milano: Franco Angeli, pp. 13-38.

Giacalone Ramat, Anna. 2002. How do learners acquire the classical three categories of temporality? Evidence from L2 Italian. In The L2 Acquisition of Tense-Aspect Morphology. Edited by M. Rafael Salaberry and Yasuhiro Shirai. Language Acquisition and Language Disorders 27. Amsterdam: John Benjamins, pp. 200-21. [CrossRef]

González, Paz, and Lucía Quintana Hernández. 2018. Inherent aspect and L1 transfer in the L2 acquisition of Spanish grammatical aspect. The Modern Language Journal 102: 611-25. [CrossRef]

Hammarberg, Björn. 2009. Introduction. In Processes in Third Language Acquisition. Edited by Björn Hammarberg. Edinburgh: Edinburgh University Press, pp. 1-16.

Howard, Martin. 2005. Les contextes prototypiques et marqués de l'emploi de l'imparfait par l'apprenant du français langue étrangère. In Nouveaux Développements de l'imparfait. Edited by Emmanuelle Labeau and Pierre Larrivée. New York and Amsterdam: Rodopi, pp. 175-97.

Izquierdo, Jesús, and Laura Collins. 2008. The facilitative role of L1 influence in tense-aspect marking: A comparison of Hispanophone and Anglophone learners of French. The Modern Language Journal 92: 350-68. [CrossRef]

Izquierdo, Jesús, and Maria Kihlstedt. 2019. L2 Imperfective functions with verb types in written narratives: A cross-sectional study with instructed Hispanophone learners of French. The Modern Language Journal 103: 291-307. [CrossRef]

Jessner, Ulrike. 2006. Linguistic Awareness in Multilinguals: English as a Third Language. Edinburgh: Edinburgh University Press.

Kihlstedt, Maria. 2002. Reference to past events in dialogue: The acquisition of tense and aspect by advanced learners of French. In The L2 Acquisition of Tense-Aspect Morphology. Edited by M. Rafael Salaberry and Yasuhiro Shirai. Language Acquisition and Language Disorders 27. Amsterdam: John Benjamins, pp. 323-62. [CrossRef]

Klein, Wolfgang. 2009. How Time is encoded. In The Expression of Time. Edited by Wolfgang Klein and Ping Li. Berlin: De Gruyter Mouton, pp. 39-82. [CrossRef]

Klein-Braley, Christine. 1985. A cloze-up on the C-Test: A study in the construct validation of authentic tests. Language Testing 2: 76-104. [CrossRef]

Klein-Braley, Christine. 1997. C-Tests in the context of reduced redundancy testing: An appraisal. Language Testing 14: 47-84. [CrossRef]

Labeau, Emmanuelle. 2005. Beyond the Aspect Hypothesis. Tense-aspect development in advanced L2 French. EUROSLA Yearbook 5: 77-101. [CrossRef]

McManus, Kevin. 2011. The Development of Aspect in a Second Language. Doctoral dissertation, Newcastle University, Newcastle upon Tyne, UK. Available online: http:/ / theses.ncl.ac.uk/jspui/handle/10443/1292 (accessed on 27 January 2021).

McManus, Kevin. 2015. L1/L2 differences in the acquisition of form-meaning pairings: A comparison of English and German learners of French. The Canadian Modern Language Review 71: 51-77. [CrossRef] 
Salaberry, M. Rafael. 2000. The Development of Past Tense Morphology in L2 Spanish. Studies in Bilingualism 22. Amsterdam: John Benjamins. [CrossRef]

Salaberry, M. Rafael. 2005. Evidence for transfer of knowledge of aspect from L2 Spanish to L3 Portuguese. In Tense and Aspect in Romance Languages: Theoretical and Applied Perspectives. Edited by Dalila Ayoun and M. Rafael Salaberry. Studies in Bilingualism 29. Amsterdam: John Benjamins, pp. 179-210. [CrossRef]

Salaberry, M. Rafael. 2008. Marking Past Tense in Second Language Acquisition. A Theoretical Model. London and New York: Continuum.

Salaberry, M. Rafael. 2020. The conceptualization of knowledge about aspect. In Third Language Acquisition: Age, Proficiency and Multilingualism. Edited by Camilla Bardel and Laura Sánchez. Eurosla Studies 3. Berlin: Language Science Press, pp. 43-65. [CrossRef]

Sánchez, Laura, and Camilla Bardel. 2017. Transfer from an L2 in third language learning: A study on L2 proficiency. In L3 syntactic Transfer: Models, New Developments and Implications. Edited by Tanja Angelovska and Angela Hahn. Amsterdam: John Benjamins, pp. 223-50. [CrossRef]

Shirai, Yasuhiro, and Roger Andersen. 1995. The acquisition of tense/aspect morphology: A prototype account. Language 71: 743-62. [CrossRef]

Smith, Carlota. 1997. The Parameter of Aspect (Studies in Linguistics and Philosophy 43). Dordrecht, Boston and London: Kluwer Academic Publishers.

Vallerossa, Francesco. 2021. L'apprendimento dell'italiano in prospettiva multilingue: Il sistema tempo-aspettuale. Paper presented at University for Foreigners of Siena, Siena, Italy, October 11.

Vallerossa, Francesco, and Camilla Bardel. Forthcoming. "He was finishing his homework or il finissait ses devoirs": A case study of multilingual students' reflections on Romance verb morphology. Manuscript in preparation.

Vallerossa, Francesco, Anna Gudmundson, Anna Bergström, and Camilla Bardel. Forthcoming. Learning aspect in Italian as additional language. The role of second languages. International Review of Applied Linguistics in Language Teaching, Submitted.

Wiberg, Eva. 1996. Reference to past events in bilingual Italian-Swedish children of school age. Linguistics 34: 1087-114. [CrossRef]

Williams, Sarah, and Björn Hammarberg. 2009. Language switches in L3 production: Implications for a polyglot speaking model. In Processes in Third Language Acquisition. Edited by Björn Hammarberg. Edinburgh: EUP, pp. 28-73, Originally in Applied Linguistics 19: 295-333. [CrossRef]

Wulff, Stefanie, Nick C. Ellis, Ute Römer, Kathleen Bardovi-Harlig, and Chelsea J. Leblanc. 2009. The acquisition of tense-aspect: Converging evidence from corpora and telicity ratings. The Modern Language Journal 93: 354-69. [CrossRef] 